\title{
Hormones and Nocturia: Guidelines for Medical Treatment?
}

An-Sofie Goessaert ${ }^{*}$, Johan Vande Walle, Ayush Kapila and Karel Everaert

Ghent University Hospital, De Pintelaan 185, 9000 Ghent, Belgium

*Corresponding author: An-Sofie Goessaert, Urology Department, Ghent University Hospital, De Pintelaan 185, 9000 Ghent, Belgium, Tel: +32 9332 3603; E-Mail: an-sofie.goessaert@uzgent.be

Received date: March 13, 2014; Accepted date: April 22, 2014; Published date: April 29, 2014

Copyright: (c) 2014 Goessaert AS, et al. This is an open-access article distributed under the terms of the Creative Commons Attribution License, which permits unrestricted use, distribution, and reproduction in any medium, provided the original author and source are credited.

\begin{abstract}
Nocturnal polyuria (NP) is an important cause of nocturia and it is related to an imbalance in water and/or sodium homeostasis. Antidiuretic hormone (ADH) and atrial natriuretic peptide (ANP) are believed to play an important role in this excessive urine production overnight, however, many other hormones are involved. ADH and ANP are both directly and indirectly influenced by the renin-angiotensin-aldosterone system (RAAS), prostaglandins antagonize both $\mathrm{ADH}$ and RAAS and sex hormones have a predominantly antidiuretic effect by stimulating ADH and RAAS, meaning that any disturbance can lead to an imbalance in diuresis. Since nocturia is a condition affecting sleep, melatonin secretion can also be affected, leading to a decrease in the antidiuretic effect and to an increase of nocturnal urine production. Depending on the underlying condition affecting any of these hormones, a more specific therapeutic approach might lead to a restoration of the normal diuresis cycle and to a good night's sleep. The characteristics of each of these hormones, the pathophysiology in NP and the therapeutic implications are set out in this review.
\end{abstract}

Keywords: Nocturnal polyuria; Antidiuretic hormone; Reninangiotensin-aldosterone; Atrial natriuretic peptide; Pathophysiology; Therapeutic implications

\section{Introduction}

Nocturia is the need to get up once or more to void at night. The underlying problem can be reduced bladder capacity, diurnal polyuria and nocturnal polyuria; each of these can be caused by several conditions. In this review we would focus on the problem of nocturnal polyuria [1]

To fully understand this topic, a basic knowledge of water and sodium homeostasis is necessary. Nocturnal polyuria due to disturbances in water handling is usually caused by an impairment of the antidiuretic hormone. If a disturbance in sodium handling seems to be the problem, natriuretic peptides are often involved [2,3]. Both of these hormones affect and are affected by the renin-angiotensinaldosterone system [4]. But there is also evidence that other hormones, such as melatonin and sex hormones affect these pathways one way or another [5,6].Therefore this article highlights the physiological mechanisms of each of these hormones and discusses how this fits in the pathophysiology of nocturnal polyuria, providing evidence for pharmacotherapeutic options.

\section{Antidiuretic Hormone}

\section{Characteristics}

$\mathrm{ADH}$ is the predominant hormone that regulates the rate of free water excretion. It is a neurohypophyseal polypeptide that is synthesized in the supraoptic and paraventricular nuclei and is secreted after migration to the posterior lobe of the pituitary as a response to the appropriate stimuli [7]. $\mathrm{ADH}$ secretion is mainly influenced by the input from the osmotic and volume receptors, with an increase due to hyperosmolality and volume depletion, respectively.
But multiple other stimuli play a role such as stress situations, nausea and hypoglycemia. Nicotine and morphine also enhance $\mathrm{ADH}$ release $[8,9]$.

There are three receptors for $\mathrm{ADH}$, by binding to the $\mathrm{V} 1$ receptor vasoconstriction and prostaglandin release occurs; stimulation of the $\mathrm{V} 1 \mathrm{~b}$ or $\mathrm{V} 3$ receptor facilitates the release of adrenocorticotropic hormone $(\mathrm{ACTH})$ in the pituitary. Activation of the $\mathrm{V} 2$ receptor mediates the antidiuretic response by fusing the $\mathrm{ADH}$-sensitive water channels, aquaporin-2, with the luminal membrane of the collecting tubules in the nephrons. This process allows water to be reabsorbed down the osmotic gradient towards the systemic circulation across the basolateral membrane. Once the ADH effect has worn off, the water channels return to the cytoplasm after endocytosis [10].

$\mathrm{ADH}$ also appears to affect electrolyte handling by enhancing sodium reabsorption and secretion of potassium in the cortical collecting tubule; however, these effects do not seem to be of major importance in maintaining the electrolyte balance $[11,12]$.

\section{NP pathophysiology}

In older people with nocturnal polyuria a decrease in nocturnal $\mathrm{ADH}$ secretion seems to be an important factor. Moon et al. and Asplund found this impaired circadian rhythm of plasma ADH levels during night time in small study samples (12 and 23 subjects, respectively) with a mean age of 68 and 71 years old, respectively $[13,14]$.

And although a loss of circadian rhythm of ADH is believed to be a normal aging process, the contribution of an impairment of this hormone is reinforced by the evidence that low nocturnal ADH levels are also found in children with nocturnal enuresis based on nocturnal polyuria [15].

Studies in which the urinary ADH levels were measured show conflicting evidence, Hirayama et al. found a decrease in urinary ADH 
excretion early in the morning in patients with NP, while Akiyama et al. showed that more than $30 \%$ of the older people $(>50$ years old, mean age 75) with NP present with increased urinary ADH excretion rates. The latter implies that not only an impaired secretion may cause $\mathrm{NP}$, but also an impaired response to $\mathrm{ADH}$, which can be caused for example by drugs and electrolyte abnormalities $[16,17]$.

\section{Therapeutical implications}

Desmopressin is a synthetic analogue of ADH and is currently the only drug approved for treatment of nocturia due to nocturnal polyuria. Compared to the endogenous $\mathrm{ADH}$, desmopressin has a pronounced antidiuretic effect and little to no vasopressor effect [18].

Desmopressin has proven to lower nocturnal urine production and to prolong the initial sleep period, thus improving the sleep quality of the patients. Beneficial effects both on short-term and long-term have been confirmed $[19,20]$. Adverse effects are limited; however, a risk for potentially fatal hyponatriemia has to be taken in account, definitely in an older population and in women who seem to be more prone to this adverse effect [21].

Renin-Angiotensin-Aldosterone System

\section{Characteristics}

The renin-angiotensin-aldosterone system is of major importance in maintaining blood pressure and fluid volume. It exerts this function through regulation of renal blood flow and solute reabsorption, thereby affecting the urine production [4].

Renin: The activity of these systems depends on the level of renin gene expression and on conversion of prorenin to active renin by proteolytic removal of a 43 amino acid prosegment. Renin is stored in secretory granules of the juxtaglomerular cells of the kidney and is released in response to various physiological stimuli, such as low blood pressure blockade of Ang II production or decreases in distal tubular sodium. It is an enzyme that triggers the cascade by cleaving the liverderived angiotensinogen into angiotensin I (Ang I) [22,23].

The major determinant of renin secretion is sodium intake; low intake or fluid loss lowers the extracellular volume and stimulates renin secretion [24]. There are three mechanisms regulating renin release. The first is through afferent arteriolar baroreceptors; in response to low arterial perfusion pressure renin release increases. The second is through sympathetic innervation of the juxtaglomerular cells, stimulation of these neurons leads to norepinephrine release and subsequent stimulation of betal-adrenergic receptors stimulating renin release. The third is a negative feedback mechanism through binding of Ang II to AT1 and AT2 receptors [25,26].

Angiotensin: Within the lungs, the inactive Ang I is converted by the angiotensin-converting enzyme (ACE) into the active angiotensin II. The effect of Ang II depends on the type of receptor that is stimulated. Binding of AngII to the AT1-receptor results in a variation of effects on vasculature, heart and kidney, such as vasoconstriction, increase of cardiac contractility and aldosterone and $\mathrm{ADH}$ secretion. Sodium reabsorption is not only stimulated indirectly through aldosterone, but also directly through stimulation of sodium transport in the early proximal tubule [22,23].

Stimulation of AT2-receptors results in the opposite effect with vasodilation and natriuresis, however, since these receptors are highly expressed in fetal tissues but then substantially regress, they are believed to be of minor importance in adults [27].

Aldosterone: Aldosterone is a mineralocorticoid hormone that is synthesized and secreted by the adrenals in response to Ang II and potassium. It stimulates mineralocorticoid receptors in the distal nephron leading to sodium reabsorption through epithelial sodium channels. The accompanying water retention expands blood and extracellular fluid volumes [28].

In situations of aldosterone overproduction, such as in primary hyperaldosteronism, an 'aldosterone escape' is seen, where the initial sodium retention is counteracted by increased ANP levels and an elevation in systemic blood pressure leading to natriuresis after 1 to 2 days in order to restore plasma volume towards normal [29].

\section{NP pathophysiology}

In children with nocturnal enuresis based on nocturnal polyuria a lack of circadian rhythm in plasma angiotensin II levels is found, which correlates with an attenuated rhythm in mean blood pressure [30]. And although evidence is limited, it has also been described that nocturnal angiotensin II levels are lower in adults with NP, together with a decrease in $\mathrm{ADH}$ [31]. Besides, a link between a non-dipping pattern in mean arterial blood pressure and nocturia in adults is found, pleading for the same underlying pathophysiologic mechanisms as found in children with nocturnal polyuria [32]. This non-dipping pattern is characterized by diminished renal sodium excretory capability, low plasma renin activity and normal aldosterone levels. The relative aldosterone excess with sodium retention during daytime leads to enhanced sodium excretion during night time [33]. In arterial hypertension higher levels of blood pressure are required to excrete the same amount of sodium, which is called pressurenatriuresis [32]. This pressure natriuresis is accomplished by increased glomerular capillary pressure, as seen in deteriorated renal function and increasing age [34].

The non-dipping pattern is also found in subjects with sodium sensitive hypertension, in whom a significant rise in blood pressure occurs as a response to sodium loading. Many factors seem to play a role in this type of hypertension, salt sensitivity is related to older age, female sex, and is possibly genetically determined. Lower renin and aldosterone levels are found in these subjects, together with a decreased number of beta2-receptors. Atrial natriuretic peptide also seems to play a role, although there is no consensus on lower levels of ANP or a lower response to ANP [35].

\section{Therapeutical implications}

In subjects with sodium sensitive hypertension a reduction in sodium intake has been proven to be effective in lowering nocturnal blood pressure and thus affecting the nocturnal sodium excretion. In high sodium load the defect in sodium excretory capability becomes more evident, leading to the above mentioned mechanisms and thus nocturnal polyuria. Sodium restriction is considered one of the most important lifestyle measures to address hypertension and renal diseases and can indirectly affect nocturnal urine production [36].

Angiotensin II type 1 receptor blockers administered in the morning seem to restore the circadian rhythms of blood pressure and natriuresis from nocturnal non-dipping to dipping patterns in patients with chronic kidney disease. This is, however, not only due to 
inhibition of the RAS itself, but mainly through enhanced renal sodium excretion during daytime [37]. This is similar to the effect of diuretics on nocturnal polyuria as described below [38].

\section{Natriuretic peptide}

\section{Characteristics}

Atrial natriuretic peptide: Atrial natriuretic peptide (ANP) is the main natriuretic hormone; it is a 28 -amino-acid polypeptide that is released from myocardial cells in the atria and in some cases the ventricles. ANP stimulates natriuretic peptide receptors (NPR) in the glomeruli and inner medullary collecting ducts [39].

This peptide functions as a direct vasodilator and also increases urinary sodium and water excretion. The latter effect is mediated by various renal and extra renal changes. The natriuretic action is primarily caused by inhibition of sodium reabsorption in the medullary collecting tubule. There still is controversy about the same effect on the proximal tubule, but in case of high ANP levels glomerular filtration rate is increased, which also leads to natriuresis [40].

But there are other pathways through which ANP exercises its natriuretic and diuretic effects, such as through the effect on the reninangiotensin-aldosterone system. In the proximal tubule, ANP inhibits the angiotensin-mediated sodium and fluid reabsorption. Besides that, ANP antagonizes the actions of aldosterone and of $\mathrm{ADH}[41,42]$.

Brain natriuretic peptide: Brain natriuretic peptide (BNP) is homologous to ANP and is present in both the brain and the heart. Circulating concentration of BNP is less than $20 \%$ of that of ANP, but in congestive heart failure patients it can easily exceed these rates [43]. The physiologic role of BNP remains to be determined, but it definitely plays a role in volume status. In ten male volunteers volume loading with an infusion of $15 \mathrm{ml} / \mathrm{kg}$ of $0.9 \% \mathrm{NaCl}$ led to a shortlasting increase of plasma NT-pro-ANP (prohormone of ANP) and a delayed increase in plasma NT-pro-BNP, together with a parallel increase in urine flow, renal excretion of sodium and NT-pro-BNP. The increased urinary NT-pro-BNP excretion during volume loading suggests a possible role of BNP in sodium homeostasis in men [44]. In a study on 74 male subjects aged 50 or older a correlation between increased NT-pro-BNP and leg edema has been found [45].
Furthermore, BNP is used for volume estimation in dialysis patients, since BNP level variations correlate positively with volume status alterations in this specific patient group [46].

\section{NP Pathophysiology}

The driving force behind excessive diuresis during night time can be a rise in nocturnal sodium excretion due to increased ANP levels. This is known to be the pathophysiological mechanism of nocturnal polyuria in patients with sleep apnea syndrome [47]. The inspiratory efforts against a closed airway during sleep apnea cause a negative intrathoracic pressure with cardiac distension that leads to the release of ANP with consequential sodium and water excretion and inhibition of both $\mathrm{ADH}$ and the renin-angiotensin-aldosterone system [48].

ANP and BNP levels are usually higher in patients with severe heart failure compared to people with normal heart function, so this is also assumed to be the mechanism of NP in patients with congestive heart failure. And although increased ANP levels have been described in the older population with NP, other studies do not observe significant differences in natriuretic peptide levels between NP patients and controls, both without cardiac failure. This suggests that NP might be a sign of undetected cardiac failure in older persons $[49,50]$.

\section{Therapeutical implications}

Furosemide is a short-acting loop diuretic often used in the treatment of heart failure or edema. When administered in the afternoon, approximately 6 hours before bedrest, it stimulates an early evening diuresis resulting in a decreased nocturnal voiding frequency [38]. This has been demonstrated in older men with lower urinary tract symptoms (LUTS) and can safely be combined with desmopressin or terazosin [51,52]. In children with desmopressinresistant nocturnal polyuria increased sodium excretion overnight was found and adding furosemide in the morning to desmopressin treatment led to an increase of diuresis of diluted urine in the morning without affecting the concentrating capacity overnight [53]. As in desmopressin treatment it is important to regularly check electrolyte balance since furosemide affects not only sodium excretion, but also enhances potassium, calcium and magnesium excretion (Table1 and Figure 1).

\begin{tabular}{|c|c|c|c|c|}
\hline & Antidiuresis & & & Diuresis \\
\hline What? & $\begin{array}{l}\text { Arginine-vasopressine } \\
\text { antidiuretic hormone }\end{array}$ & Angiotensine II & Aldosterone & Atrial natriuretic peptie \\
\hline Site of synthesis? & Neurohypophysis & Lungs & Adrenal glands & Atria \\
\hline Site of effect in kidney? & $\begin{array}{l}\text { Cortical and medullary collecting } \\
\text { tubule }\end{array}$ & Proximal tubule & $\begin{array}{l}\text { Cortical collecting tubule } \\
\text { (epithelial sodium channels) }\end{array}$ & $\begin{array}{l}\text { Glomeruli \& inner medullary collecting } \\
\text { duct }\end{array}$ \\
\hline Receptors? & V2-receptor & AT1-receptor & MR-receptor & NPR-A \\
\hline Main effect in kidney? & $\begin{array}{l}\text { Antidiuresis through water } \\
\text { reabsorption by fusion of } \\
\text { aquaporin-2 channels with } \\
\text { luminal membrane }\end{array}$ & $\begin{array}{l}\text { Antidiuresis through: } \\
\text { Sodium reabsorption, both } \\
\text { directly and indirectly } \\
\text { (stimulation of aldosterone } \\
\text { secretion) }\end{array}$ & $\begin{array}{l}\text { Antidiuresis through sodium } \\
\text { reabsorption }\end{array}$ & $\begin{array}{l}\text { Natriuresis through: } \\
\text { inhibition of sodium reabsorption } \\
\text { directly and indirectly (inhibition of } \\
\text { RAAS) } \\
\text { inhibition of water reabsorption } \\
\text { indirectly (diminish response to ADH) }\end{array}$ \\
\hline
\end{tabular}




\begin{tabular}{|c|c|c|c|c|}
\hline & & $\begin{array}{l}\text { Water reabsorption, indirectly } \\
\text { (sodium reabsorption and } \\
\text { stimulation of } A D H \text { ) }\end{array}$ & & \\
\hline Stimulating factors? & $\begin{array}{l}\text { Hyperosmolality } \\
\text { Hypovolemia } \\
\text { stress e.g. pain } \\
\text { hypoglycemia }\end{array}$ & $\begin{array}{l}\text { Increase in renin due to: } \\
\text { Low blood volume } \\
\text { Low } \mathrm{Na}+\text { concentration in } \\
\text { distal tubule } \\
\text { Drop in blood pressure }\end{array}$ & $\begin{array}{l}\text { Ang II } \\
\text { Plasma K+ concentration } \\
\text { ACTH }\end{array}$ & $\begin{array}{l}\text { Volume expansion with atrial stretch } \\
\text { Aldosterone escape }\end{array}$ \\
\hline Role in nocturnal polyuria? & $\begin{array}{l}\text { Reduced e.g. in nocturnal } \\
\text { enuresis }\end{array}$ & Reduced e.g. in hypertension & $\begin{array}{l}\text { Reduced e.g. sleep apnea } \\
\text { syndrome }\end{array}$ & Increased e.g. in heart failure \\
\hline
\end{tabular}

Table 1: Main antidiuretic and diuretic hormones and characteristics

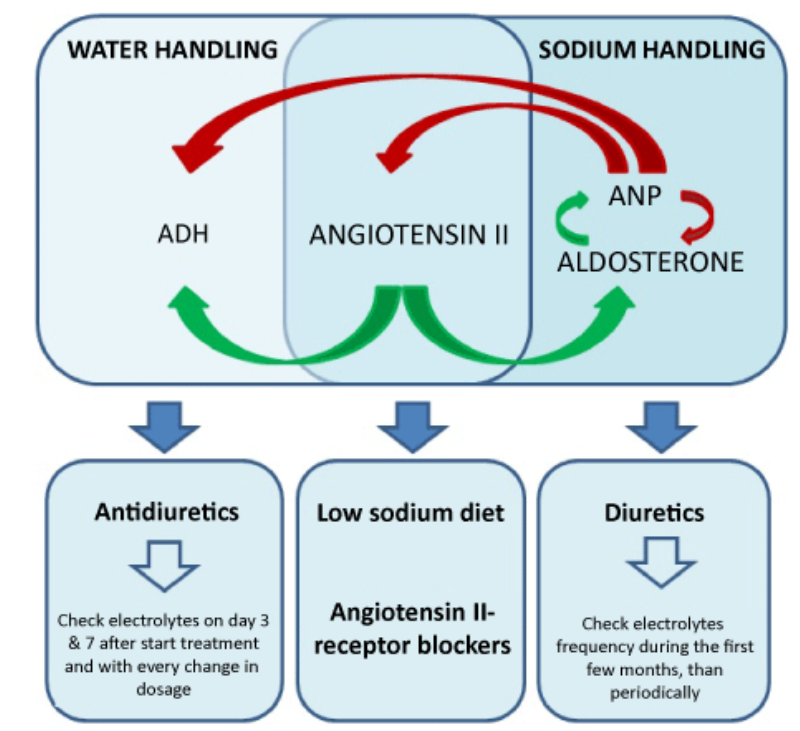

Figure 1: Stimulating and inhibiting effects of hormones involved in water and sodium handling and therapeutical implications

\section{Other hormones}

Prostaglandins: Prostaglandins are derivatives from the metabolism of arachidonic acid, catalyzed by the coclooxygenase (COX) enzyme. In the kidney, COX-1 controls renal hemodynamics and glomerular filtration rate, COX-2 plays a role in salt and water excretion [54].

Prostaglandin E2 (PGE2) is synthesized both in the glomeruli and tubules, it lowers the renal vascular resistance and increases renal perfusion through dilatation of the renal vascular bed. The tubular effect of PGE2 is an antagonistic effect of ADH and thus implies local modulation of water and electrolyte transport; however, the major function of the $\mathrm{ADH}$-prostaglandin relationship may be the regulation or renal hemodynamics [55]. ProstaglandinI2 (PGI2) or prostacyclin is synthesized in the glomeruli and mainly affects renal homeostatic mechanisms by antagonizing the vasoconstrictor effects of both norepinephrine and angiotensin II in the vessels [54,55]. The effects of ANP are also influenced by prostaglandins, since the ANP-related natriuresis seems to depend on redistribution of renal blood flow due to an increase in urinary excretion of prostaglandins and a decrease of renin secretion [56].

Since prostaglandins are synthezised through COX-enzymes, a beneficial effect of non-steroidal anti-inflammatory drugs in some patients with nocturia is not surprising. A Japanese study in which men with benign prostate hypertrophy (BPH) were treated with loxoprofen because BPH treatment did not improve nocturia, reported in $74 \%$ of the cases an improvement or disappearance of nocturia [57]. Treatment of 26 patients with nocturnal polyuria with diclofenac gave a significant decrease in nocturia episodes from 2.7 to 2.3 and a significant decrease in ratio of night time to $24 \mathrm{~h}$ urine volume from $44 \%$ to $39 \%$, however, clinical relevance of these decreases is doubtful [58]. The effect of NSAIDs on nocturia can be explained through several pathways: reduction of urine production at the kidney, decrease in urinary sensation at the bladder, increase of urinary sensation threshold at the central nervous system or alteration of sleep at the brain. However, PGE2 and PGI2 normally only start playing an important role in maintaining GFR in patients with compromised renal hemodynamics. This means that a good effect of NSAIDs is mainly expected in older patients or patients with congestive heart failure, cirrhosis or nephrosis, but since there is a risk of gastric ulcers and deterioration of kidney function, NSAIDs are not indicated to be used in older or precarious patients. Most common reported adverse events in treatment with NSAIDs for nocturia are gastric discomfort, leg edema and urinary frequency in the morning [57,58].

Melatonin: Melatonin is a pineal hormone that is particularly known for its circadian secretion rhythm with a prominent nocturnal peak as a response to the light-dark rhythm. It also influences the circadian rhythm of other hormones and since the melatonin (MT) receptors are distributed throughout the whole body, it has a large variation in effects [59]. These effects also imply an influence of the above mentioned hormones.

A colocalization of melatonin receptors and $\mathrm{ADH}$ neurons in the suprachiasmatic, paraventricular and supraoptic nuclei has been described, suggesting that melatonin might directly modulate the hypothalamic-pituitary-adrenal axis and thus might also have an impact on the antidiuretic effect of $\mathrm{ADH}$ [60]. Besides, a reninangiotensin system in the brain seems to modulate melatonin 
synthesis. Interaction between locally produced angiotensin II and melatonin in the pineal gland affects the peripheral renin-angiotensin system and thus indirectly urine production [5]. The relation between neuroendocrine functions and the cardiovascular system might also be regulated through ANP, since acute injections of ANP stimulate melatonin secretion, however, administration of oral melatonin does not seem to affect ANP plasma concentrations; the true link between melatonin and ANP remains to be elucidated [61,62].

Only few studies are performed with melatonin as treatment for nocturia. One study examined the effect of $2 \mathrm{mg}$ melatonin on nocturia compared to placebo in patients with benign prostate hyperplasia. A statistically significant difference in nocturia episodes was found, however, a reduction of 0.32 episodes does not seem clinically relevant. Besides, since it was studied in a population with $\mathrm{BPH}$, it is difficult to estimate the influence of $\mathrm{BPH}$ on nocturia and on the effect of melatonin treatment [63]. Another study comparing the effect of melatonin and rilmazafone, a hypnotic agent, on nocturia also showed a significant decrease in nocturia episodes, together with an increase in the serum melatonin levels. Before treatment, all patients considered their nocturia problem as bothersome, after 4 weeks of treatment, $70 \%$ of the patients considered it to be no longer bothersome.

Although the link between sleep disorders and nocturia has not been elucidated yet, it is certain that there is a relation between both and it is important to counsel about the presence of sleep disturbances when considering treatment for nocturia.

Sex hormones: In women, estrogens and progestogens are the main sex hormones. Estrogens are steroid hormones synthesized from androgens under stimulation of follicle stimulating hormone by the ovaries and in lower concentrations by the liver, adrenal glands, breasts and fat. Action of estrogens is mediated by the estrogen receptor, resulting in various effects on menstrual cycle, sexual characteristics et cetera [64].

Progesterone is also a steroid hormone synthesized from the cholesterol-derived pregnenolone by the ovaries and adrenal glands. It is the precursor of aldosterone and after conversion into 17hydroxyprogesterone of cortisol and androstenedione, the latter can be converted to testosterone, estrone and estradiol. Progesterone binds to the progesterone receptor and has key effects in the reproductive system and nervous system [65].

Testosterone is in small amounts present in women, but is the main sex hormone in men. Like the other steroid hormones, it is derived from cholesterol. Testosterone exerts its effect through binding to the androgen receptor at one hand and by conversion to estradiol and activation of estrogen receptors at the other hand. It plays a key role in the development of male reproductive tissues such as testes and prostate, it is necessary for normal sperm development and promotes secondary sexual characteristics. Furthermore, testosterone is essential for general well-being [66].

$\mathrm{ADH}$ secretion is subjected to circadian rhythms, but also to the menstrual cycle in women. Increased basal and nocturnal $\mathrm{ADH}$ concentrations are found in the midfollicular phase of the menstrual cycle; postmenopausal women who take in estrogen will have increased $\mathrm{ADH}$, whereas the combination of estrogen and progesterone lowers the $\mathrm{ADH}$ concentrations [67-69].
High estrogen states decrease baseline plasma-osmolality and sodium by resetting of the osmoreceptors for thirst and $\mathrm{ADH}$ release. However, in this situation $\mathrm{ADH}$ secretion persists and slightly hypotonic plasma is maintained [67]. Another study suggests that 3beta- 17beta-estradiol (E2) augments osmotic ADH secretion with water retention as a consequence, however, the enhanced fluid retention was mainly based on an increase in renal sodium reabsorption [68].

The effects on sodium excretion can be attributed to the relation between estrogens and progestogens and the renin-aldosterone system. High doses of estrogens stimulate the synthesis of angiotensinogen and the consecutive increase in angiotensin II slightly reduces renal blood flow and increases sodium and blood pressure. At the other hand, endogenous or exogenous progesterone promotes sodium loss which leads to a compensatory increase in the activity of the renin-angiotensin-aldosterone system. Combination treatment of ethinylestradiol and progestogens may therefore enhance the estrogen effects on body sodium and blood pressure, also since some synthetic progestogens are weak estrogen receptor agonists [6].

Literature on the link between androgens and the hormones involved in the water and sodium homeostasis is limited. Men seem to have higher plasma concentrations of ADH compared to women and present with a higher sensitivity in $\mathrm{ADH}$ response [68]. Gender differences in blood pressure are attributed to the relation between androgens and the renin-aldosterone system. A greater activation of the RAS with higher blood pressure levels in males is partly attributed to these androgens. Castration seems to result in a normalization of blood pressure and downregulation of the intrarenal RAS [70].

Athough some studies do not report an effect, several other studies have shown a beneficial effect of estrogen on the symptom of nocturia [71]. As well oral administration as topical application of estrogen in postmenopausal women leads to a significant decrease in nocturnal frequency within 3 months after the beginning of the therapy [72]. A trial with $2 \mathrm{mg} 17$ beta-oestradiol combined with $2.5,5,10$ or $15 \mathrm{mg}$ dydrogesterone led to complete cure of nocturia in $65 \%$ of the 26 postmenopausal women with baseline nocturia who completed 6 months of hormonal therapy [73]. A randomized controlled trial studying the effect of oestradiol-releasing rings and oestriol pessaries in postmenopausal women showed a decrease in the number of nocturia episodes of $51 \%$ and $54 \%$, respectively [74]. So regardless of the type of estrogen replacement therapy that is used, an effect on nocturia can be seen.

No direct effect of testosterone on nocturia has been described, but drugs that indirectly target testosterone such as 5-alpha-reductase inhibitors seem to have an effect on nocturia, however, the effect is rather small. Doxazosin and combination therapy with finasteride resulted in a larger reduction of nocturia-episodes than placebo, but the net difference was less than 0.20 fewer nocturnal voiding episodes at 1 and 4 years [75] (Table 2).

\begin{tabular}{|l|l|l|l|}
\hline Hormones & Main effect & Consequence & $\begin{array}{l}\text { Therapeutical } \\
\text { implication for NP }\end{array}$ \\
\hline $\begin{array}{l}\text { Prostaglandins: } \\
\text { PGE2 }\end{array}$ & $\begin{array}{l}\text { ? antagonizes ADH } \\
\text { ? antagonizes RAAS }\end{array}$ & Diuresis & NSAIDs \\
\hline Melatonin & stimulates ADH & Antidiuresis & Melatonin \\
\hline
\end{tabular}




\begin{tabular}{|c|c|c|c|}
\hline $\begin{array}{l}\text { Sex hormones: } \\
\text { estrogens } \\
\text { progesterone }\end{array}$ & $\begin{array}{l}\text { ? stimulates ADH, } \\
\text { Renin, Ang II, ANP; } \\
\text { inhibits Aldosteron } \\
\text { ? stimulates Aldosteron; } \\
\text { antagonizes ADH, ANP }\end{array}$ & Antidiuresis & $\begin{array}{l}\text { Replacement } \\
\text { therapy } \\
\text { necessary }\end{array}$ \\
\hline testosterone & $\begin{array}{l}? \quad \text { stimulates } \\
\text { Renin, Ang II }\end{array}$ & & \\
\hline
\end{tabular}

PGE2: Prostaglandin E2; PGI2: Prostaglandin I2; ADH: Antidiuretic Hormone; RAAS: Renin-Angiotensin-Aldosterone System; ANP: Atrial Natriuretic Peptide; NSAIDs: Non-Steroidal Anti-Inflammatory Drugs

Table 2: Influence of prostaglandins, melatonin and sex hormones on the antidiuretic and diuretic hormones

\section{Conclusion}

Different hormonal pathways are involved in urine production. With increasing age circadian rhythms of these hormones vanish, making older people more susceptible to a large nocturnal urine production. However, at any age, it is an imbalance in this hormonal regulation that can lead to an excessive urine production and thus nocturnal polyuria.

Addressing the underlying pathologies that affect either directly or indirectly water or sodium handling and thus urine production can relieve people from bothersome nocturia or nocturnal urinary incontinence based on nocturnal polyuria and can improve both their sleep quality and quality of life.

\section{References}

1. Cornu JN, Abrams P, Chapple CR, Dmochowski RR, Lemack GE, et al (2012) A contemporary assessment of nocturia: definition, epidemiology, pathophysiology, and management--a systematic review and metaanalysis. Eur Urol 62: 877-890.

2. Herek J, Fitzgerald M, Mohindra M, Wickman C, Leehey J, et al (2010) Solute and Water Excretion Patterns in Patients with Nocturnal Polyuria. International Journal of Nephro-Urology 2: 526-531.

3. Miller M (2000) Nocturnal polyuria in older people: pathophysiology and clinical implications. J Am Geriatr Soc 48: 1321-1329.

4. Carey RM, Siragy HM (2003) Newly recognized components of the renin-angiotensin system: Potential roles in cardiovascular and renal regulation. Endocrine Reviews 24: 261-271.

5. Campos LA, Cipolla-Neto J, Amaral FG, Michelini LC, Bader M, et al. (2013) The Angiotensin-melatonin axis. Int J Hypertens 2013: 521783.

6. Oelkers WK (1996) Effects of estrogens and progestogens on the reninaldosterone system and blood pressure. Steroids 61: 166-171.

7. Zimmerman EA, Nilaver G, Hou-Yu A, Silverman AJ (1984) Vasopressinergic and oxytocinergic pathways in the central nervous system. Fed Proc 43: 91-96.

8. Sladek CD (1983) Regulation of vasopressin release by neurotransmitters, neuropeptides and osmotic stimuli. Prog Brain Res 60: 71-90.

9. Robertson GL, Athar S (1976) The interaction of blood osmolality and blood volume in regulating plasma vasopressin in man. J Clin Endocrinol Metab 42: 613-620.

10. Birnbaumer M (2000) Vasopressin receptors. Trends Endocrinol Metab 11: 406-410.

11. Lencer WI, Brown D, Ausiello DA, Verkman AS (1990) Endocytosis of water channels in rat kidney: cell specificity and correlation with in vivo antidiuresis. Am J Physiol 259: C920-932.

12. Field MJ, Stanton BA, Giebisch GH (1984) Influence of ADH on renal potassium handling: a micropuncture and microperfusion study. Kidney Int 25: 502-511.
13. Asplund R (2002) Diuresis pattern, plasma vasopressin and blood pressure in healthy elderly persons with nocturia and nocturnal polyuria. Neth J Med 60: 276-280.

14. Moon DG, Jin MH, Lee JG, Kim JJ, Kim MG, et al. (2004) Antidiuretic hormone in elderly male patients with severe nocturia: a circadian study. BJU Int 94: 571-575.

15. AbdelFatah D, Shaker H, Ismail M, Ezzat M (2009) Nocturnal polyuria and nocturnal arginine vasopressin (AVP): a key factor in the pathophysiology of monosymptomatic nocturnal enuresis. Neurourol Urodyn 28: 506-509.

16. Akiyama T, Hirayama A, Fujimoto $\mathrm{K}$, Torimoto $\mathrm{K}$, Yoshida $\mathrm{K}$, et al. (2007) Cutoff value of urinary arginine vasopressin for nocturnal polyuria in elderly men. Urology 69: 98-102.

17. Hirayama A, Fujimoto K, Akiyama T, Hirao Y (2006) Decrease in nocturnal urinary levels of arginine vasopressin in patients with nocturnal polyuria. Urology 68: 19-23.

18. CvetkoviÄ RS, Plosker GL (2005) Desmopressin: in adults with nocturia. Drugs 65: 99-107.

19. Chang YL, Lin AT, Chen KK (2007) Short-term effects of desmopressin on water and electrolyte excretion in adults with nocturnal polyuria. J Urol 177: 2227-2229.

20. Juul KV, Klein BM, Nørgaard JP (2013) Long-term durability of the response to desmopressin in female and male nocturia patients. Neurourol Urodyn 32: 363-370.

21. Juul KV, Klein BM, Sandström R, Erichsen L, Nørgaard JP (2011) Gender difference in antidiuretic response to desmopressin. Am J Physiol Renal Physiol 300: F1116-1122.

22. Griendling KK, Murphy TJ, Alexander RW (1993) Molecular biology of the renin-angiotensin system. Circulation 87: 1816-1828.

23. Paul M, Poyan Mehr A, Kreutz R (2006) Physiology of local reninangiotensin systems. Physiol Rev 86: 747-803.

24. MacGregor GA, Markandu ND, Roulston JE, Jones JC, Morton JJ (1981) Maintenance of blood pressure by the renin-angiotensin system in normal man. Nature 291: 329-331.

25. Kurtz A (2011) Renin release: sites, mechanisms, and control. Annu Rev Physiol 73: 377-399.

26. Friis UG, Madsen K, Stubbe J, Hansen PB, Svenningsen P, et al. (2013) Regulation of renin secretion by renal juxtaglomerular cells. Pflugers Arch 465: 25-37.

27. Crowley SD, Gurley SB, Oliverio MI, Pazmino AK, Griffiths R, et al. (2005) Distinct roles for the kidney and systemic tissues in blood pressure regulation by the renin-angiotensin system. J Clin Invest 115: 1092-1099.

28. Funder JW, Mihailidou AS (2009) Aldosterone and mineralocorticoid receptors: Clinical studies and basic biology. Mol Cell Endocrinol 301: $2-6$.

29. Granger JP, Burnett JC Jr, Romero JC, Opgenorth TJ, Salazar J, et al. (1987) Elevated levels of atrial natriuretic peptide during aldosterone escape. Am J Physiol 252: R878-882.

30. Rittig S, Matthiesen TB, Pedersen EB, Djurhuus JC (2006) Circadian variation of angiotensin II and aldosterone in nocturnal enuresis: relationship to arterial blood pressure and urine output. J Urol 176: 774-780.

31. Matthiesen TB, Rittig S, Nørgaard JP, Pedersen EB, Djurhuus JC (1996) Nocturnal polyuria and natriuresis in male patients with nocturia and lower urinary tract symptoms. J Urol 156: 1292-1299.

32. Feldstein CA (2013) Nocturia in arterial hypertension: a prevalent, underreported, and sometimes underestimated association. J Am Soc Hypertens 7: 75-84.

33. Satoh M, Kikuya M, Ohkubo T, Mori T, Metoki H, et al. (2011) Aldosterone-to-renin ratio and nocturnal blood pressure decline in a general population: the Ohasama study. J Hypertens 29: 1940-1947.

34. Pelayo JC, Harris DC, Shanley PF, Miller GJ, Schrier RW (1988) Glomerular hemodynamic adaptations in remnant nephrons: effects of verapamil. Am J Physiol 254: F425-431. 
35. Weinberger MH (1996) Salt sensitivity of blood pressure in humans. Hypertension 27: 481-490.

36. Uzu T, Ishikawa K, Fujii T, Nakamura S, Inenaga T, et al. (1997) Sodium restriction shifts circadian rhythm of blood pressure from nondipper to dipper in essential hypertension. Circulation 96: 1859-1862.

37. Fukuda M, Wakamatsu-Yamanaka T, Mizuno M, Miura T, Tomonari T, et al.( 2011) Angiotensin receptor blockers shift the circadian rhythm of blood pressure by suppressing tubular sodium reabsorption. Am J Physiol Renal Physiol 301:953-957.

38. Reynard JM, Cannon A, Yang Q, Abrams P (1998) A novel therapy for nocturnal polyuria: a double-blind randomized trial of frusemide against placebo. Br J Urol 81: 215-218.

39. Cho Y, Somer BG, Amatya A (1999) Natriuretic peptides and their therapeutic potential. Heart Dis 1: 305-328.

40. Chopra S, Cherian D, Verghese PP, Jacob JJ (2013) Physiology and clinical significance of natriuretic hormones. Indian J Endocrinol Metab 17: 83-90.

41. Ganguly A (1992) Atrial natriuretic peptide-induced inhibition of aldosterone secretion: a quest for mediator(s) Am J Physiol 263: E181-194.

42. Nonoguchi H, Sands JM, Knepper MA (1988) Atrial Natriuretic Factor Inhibits Vasopressin-Stimulated Osmotic Water Permeability in Rat Inner Medullary Collecting Duct. J Clin Invest 82:1383-1390.

43. Mukoyama M, Nakao K, Hosoda K, Suga S, Saito Y, et al. (1991) Brain Natriuretic Peptide As A Novel Cardiac Hormone in Humans - Evidence for An Exquisite Dual Natriuretic Peptide System, Atrial-NatriureticPeptide and Brain Natriuretic Peptide. J Clin Invest 87:1402-1412.

44. Heringlake M, Heide C, Bahlmann L, Eichler W, Pagel H, et al. (2004) Effects of tilting and volume loading on plasma levels and urinary excretion of relaxin, NT-pro-ANP, and NT-pro-BNP in male volunteers. J Appl Physiol (1985) 97:173-179.

45. Hirayama A, Torimoto K, Yamada A, Tanaka N, Fujimoto K, et al. (2011) Relationship between nocturnal urine volume, leg edema, and urinary antidiuretic hormone in older men. Urology 77: 1426-1431.

46. Roueff S, Martin E, Chauffert ML, Poli I, Kihal K, et al. (2008) Brain natriuretic peptide variations are linked to volume status in hemodialysis patients. Clin Nephrol 70: 508-513.

47. Bing MH, Jennum P, Moller LA, Mortensen S, Lose G (2012) Obstructive sleep apnea in a Danish population of men and women aged 60-80 years with nocturia. J Clin Sleep Med 8: 515-520.

48. Umlauf MG, Chasens ER (2003) Sleep disordered breathing and nocturnal polyuria: nocturia and enuresis. Sleep Med Rev 7: 403-411.

49. Carter PG, Cannon A, McConnell AA, Abrams P (1999) Role of atrial natriuretic peptide in nocturnal polyuria in elderly males. Eur Urol 36: 213-220.

50. Torimoto K, Hirayama A, Samma S, Yoshida K, Fujimoto K, et al. (2009) The relationship between nocturnal polyuria and the distribution of body fluid: assessment by bioelectric impedance analysis. J Urol 181: 219-224.

51. Cho MC, Ku JH, Paick JS (2009) Alpha-Blocker Plus Diuretic Combination Therapy as Second-line Treatment for Nocturia in Men With LUTS: A Pilot Study. Urology 73:549-553.

52. Fu FG, Lavery HJ, Wu DL (2011) Reducing nocturia in the elderly: a randomized placebo-controlled trial of staggered furosemide and desmopressin. Neurourol Urodyn 30: 312-316.

53. De Guchtenaere A, Vande Walle C, Van Sintjan P, Donckerwolcke R, Raes A, et al. (2007) Desmopressin resistant nocturnal polyuria may benefit from furosemide therapy administered in the morning. J Urol 178: 2635-2639.

54. Weir MR (2002) Renal effects of nonselective NSAIDs and coxibs. Cleve Clin J Med 69 Suppl 1: SI53-58.

55. Schlondorff D (1986) Renal prostaglandin synthesis. Sites of production and specific actions of prostaglandins. Am J Med 81: 1-11.
56. Salazar FJ, Bolterman R, Hernandez I, Quesada T, Romero JC (1987) Role of prostaglandin and angiotensin II in ANP-induced natriuresis. Agents Actions Suppl 22: 111-123.

57. Araki T, Yokoyama T, Kumon H (2004) Effectiveness of a nonsteroidal anti-inflammatory drug for nocturia on patients with benign prostatic hyperplasia: a prospective non-randomized study of loxoprofen sodium $60 \mathrm{mg}$ once daily before sleeping. Acta Med Okayama 58: 45-49.

58. Addla SK, Adeyoju AB, Neilson D, O'Reilly P(2006) Diclofenac for treatment of nocturia caused by nocturnal polyuria: A prospective, randomised, double-blind, placebo-controlled crossover study. European Urology 49:720-725.

59. Hardeland R (2012) Neurobiology, pathophysiology, and treatment of melatonin deficiency and dysfunction. ScientificWorldJournal 2012: 640389.

60. Wu YH, Zhou JN, Balesar R, Unmehopa U, Bao AM, et al. (2006) Distribution of MT1 melatonin receptor immunoreactivity in the human hypothalamus and pituitary gland: Colocalization of MT1 with vasopressin, oxytocin, and corticotropin-releasing hormone. J Comp Neurol 499: 897-910.

61. Lissoni P, Pelizzoni F, Perego M, Fondrini G, Grugni G, et al. (1990) A study of heart-pineal interactions: atrial natriuretic peptide response to melatonin administration in healthy humans. J Pineal Res 9: 167-170.

62. Lissoni P, Pelizzoni F, Grugni G, Guzzaloni G, Mauri O, et al. (1990) Melatonin Response to Atrial-Natriuretic-Peptide Administration in Healthy-Volunteers. J Cardiovasc Pharmacol 16:850-852.

63. Drake MJ, Mills IW, Noble JG (2004) Melatonin pharmacotherapy for nocturia in men with benign prostatic enlargement. J Urol 171: 1199-1202.

64. Gruber CJ, Tschugguel W, Schneeberger C, Huber JC (2002) Production and actions of estrogens. N Engl J Med 346: 340-352.

65. Graham JD, Clarke CL (1997) Physiological action of progesterone in target tissues. Endocr Rev 18: 502-519.

66. Shahidi NT (2001) A review of the chemistry, biological action, and clinical applications of anabolic-androgenic steroids. Clin Ther 23: 1355-1390.

67. Graugaard-Jensen C, Hvistendahl GM, Frøkiaer J, Bie P, Djurhuus JC (2008) The influence of high and low levels of estrogen on diurnal urine regulation in young women. BMC Urol 8: 16

68. Stachenfeld NS, DiPietro L, Palter SF, Nadel ER (1998) Estrogen influences osmotic secretion of AVP and body water balance in postmenopausal women. Am J Physiol 274:187-195.

69. Vokes TJ, Weiss NM, Schreiber J, Gaskill MB, Robertson GL (1988) Osmoregulation of thirst and vasopressin during normal menstrual cycle. Am J Physiol 254: R641-647.

70. Maric-Bilkan C, Manigrasso MB (2012) Sex differences in hypertension: contribution of the renin-angiotensin system. Gend Med 9: 287-291.

71. Moehrer B, Hextall A, Jackson S (2003). Oestrogens for urinary incontinence in women. Cochrane Database Syst Rev 2: CD001405.

72. Long CY, Liu CM, Hsu SC, Chen YH, Wu CH, et al. (2006) A randomized comparative study of the effects of oral and topical estrogen therapy on the lower urinary tract of hysterectomized postmenopausal women. Fertil Steril 85: 155-160.

73. Kok AL, Burger CW, van de Weijer PH, Voetberg GA, Peters-Muller ER, et al. (1999) Micturition complaints in postmenopausal women treated with continuously combined hormone replacement therapy: a prospective study. Maturitas 31: 143-149.

74. Lose G, Englev E (2000) Oestradiol-releasing vaginal ring versus oestriol vaginal pessaries in the treatment of bothersome lower urinary tract symptoms. BJOG 107: 1029-1034.

75. Johnson TM 2nd, Burrows PK, Kusek JW, Nyberg LM, Tenover JL, et al. (2007) The effect of doxazosin, finasteride and combination therapy on nocturia in men with benign prostatic hyperplasia. J Urol 178: 2045-2050. 